\title{
Estimasi Debit Puncak Menggunakan Hidrograf Satuan Sintetik Pada Daerah Aliran Sungai Kayan Kabupaten Bulungan
}

\author{
Asta $^{* 1}$, Nurjaya $^{2}$ \\ Jurusan Teknik Sipil, Fakultas Teknik, Universitas Borneo Tarakan \\ E-mail : 'asta.ubt@gmail.com
}

Received 18 Agustus 2019; Reviewed 07 September 2019; Accepted 28 November 2019

Journal Homepage: http://jurnal.borneo.ac.id/index.php/borneoengineering

\begin{abstract}
The Kayan Watershed in Bulungan Regency is the largest river in North Kalimantan which has the potential for flooding in several irrigated points. Kayan River is a flood-prone area and prioritized to be handled immediately because there is already a smooth life for the community. Potentially need to know the great potential of flooding in the Kayan River. To find out the relationship between flood discharge and flood time, the Synthetic Unit Hydrograph calculation method is used. The aim is to determine the shape and results of peak discharge in Synthetic Unit Hydrograph $Y$ (SUH). This study uses a debit calculation in the Kayan watershed using Snyder HSS and Nakayasu HSS. From the calculation results obtained Snyder SUH peak discharge of $118.0 \mathrm{m3} / \mathrm{sec}$ at 73.85 hours, and Nakayasu SUH has a peak discharge of $109.35 \mathrm{m3} / \mathrm{sec}$ at 54.09 hours.
\end{abstract}

Keywords: Kayan river, SUH, flood discharge, Snyder, Nakayasu

\begin{abstract}
Abstrak
Daerah Aliran Sungai (DAS) Kayan di Kabupaten Bulungan merupakan sungai terbesar di Kalimantan Utara yang mempunyai potensi banjir di sejumlah titik. Sungai Kayan menjadi daerah yang berpotensi banjir dan diproritaskan untuk segera ditangani karena akan mengganggu kelancaran kehidupan masyarakat disekitarnya.Sehingga perlu diketahui besar potensi banjir di Sungai Kayan. Untuk mengetahui hubungan antara debit banjir dan waktu puncak banjir digunakan metode perhitungan Hidrograf Satuan Sintetik (HSS). Tujuan adalah mengetahui bentuk dan hasil debit puncak pada Hidrograf Satuan Sintetis (HSS). Penelitian ini menggunakan perhitungan debit pada DAS Kayan menggunakan HSS Snyder dan HSS Nakayasu. Dari hasil perhitungan diperoleh debit puncak HSS Snyder sebesar 118,0 $\mathrm{m}^{3} /$ det pada waktu 73.85 jam, dan HSS Nakayasu memiliki debit puncak sebesar 109,35 $\mathrm{m}^{3} /$ det pada waktu 54,09 jam.
\end{abstract}

Kata kunci : DAS Kayan, HSS, Debit Banjir, Snyder, Nakayasu

\section{Pendahuluan}

Sungai Kayan adalah sungai terbesar di Kalimantan Utara dengan panjang sungai utama mencapai $576 \mathrm{Km}$ dan luas $33.005 \mathrm{Km} 2$ (studi terdahulu rancangan pola PSDA WS.Kayan 2009). Sungai ini mempunyai potensi banjir di sejumlah titik yang dialiri. Banjir tersebut juga disebabkan oleh karakteristik DAS Kayan yang mempunyai 3 area penampungan hujan di hulu dan hanya memiliki satu aliran sungai utama. Karakteristik lain yang memicu terjadinya banjir adalah tanah di bagian hulu berupa tanah podsol berwarna coklat hasil bentukan hujan. Tanah ini rentan akan curah hujan yang mengakibatkan erosi dan terikut oleh arus air. 
Sungai Kayan menjadi daerah rawan banjir dan harus dijadikan prioritas untuk segera ditangani, hal ini dikarenakan banjir yang terjadi sudah mengganggu dan merusak kelancaran ekonomi, sarana dan prasarana kehidupan masyarakat. Sehingga perlu diketahui seberapa besar potensi banjir di Sungai Kayan. Oleh karena hal ini, debit aliran sungai merupakan hal yang sangat penting untuk dikaji dalam prakiraan banjir. Metode hidrologi yang banyak digunakan untuk menganalisis debit sungai untuk prakiraan banjir adalah hidrograf satuan.

Hidrograf satuan tersebut dapat dibuat apabila tersedia data seperti data rekaman Automatic Water Level Recorder (AWLR), data pengukuran debit, dan juga data hujan. Akan tetapi, data-data tersebut tidak selalu ada pada tiap wilayah. Sehingga dikembangkan suatu metode prakiraan banjir yang disebut hidrograf satuan sintetis (HSS).

Hidrograf satuan sintetis (HSS) adalah salah satu perhitungan debit puncak yang menggunakan karakteristik DAS sebagai parameternya. Terdapat banyak sekali model hidrograf satuan sintetis yang telah dikembangkan baik di Indonesia maupun di luar negeri, untuk mengatasi ketersediaan data di wilayah-wilayah yang akan dikaji. Metode hidrograf satuan sintetis yang saat ini umum digunakan di Indonesia antara lain adalah metode Snyder, Snyder-Alexeyev, Nakayasu, GAMA1, HSS- $\alpha \beta \gamma$ dan Limantara. metoda HSS Snyder, HSS GAMA-1, dan HSS Nakayasu. Metoda HSS Snyder dan HSS Nakayasu dikembangkan diluar negeri, sedangkan metode HSS GAMA-1 adalah perhitungan hidrograf satuan sintetis yang pertama dikembangkan di Indonesia tepatnya di Universitas Gajah Mada.

Teori klasik hidrograf satuan berasal dari hubungan antara hujan efektif dengan limpasan langsung. Hubungan tersebut merupakan salah satu komponen model watershed yang umum. Teori hidrograf satuan merupakan penerapan pertama teori system linier dalam hidrologi (Soemarto,1987 dalam Bambang Triatmodjo,2008). Sherman pada 1932 (dalam Bambang Triatmodjo,2008) mengenalkan konsep hidrograf satuan, yang banyak digunakan untuk melakukan transformasi dari hujan menjadi debit aliran. Hidrograf satuan didefinisikan sebagai hidrograf limpasan langsung (tanpa aliran dasar) yang tercatat diujung hilir DAS yang ditimbulkan oleh hujan efektif sebesar $1 \mathrm{~mm}$ yang terjadi secara merata di permukaan DAS dengan intensitas tetap dalam suatu durasi tertentu.

Hidrograf satuan merupakan hidrograf limpasan langsung yang dihasilkan oleh hujan yang terjadi merata diseluruh DAS dan dengan intensitas tetap dan dalam satuan waktu yang ditetapkan (Sri Harto,1993). Hidrograf satuan ini sangat dipengaruhi oleh dua hal yaitu karakteristik DAS dan iklim. Karakteristik DAS yang dimaksuk adalah morfometri DAS yang terdiri dari luas DAS, median elevasi, kemiringan sungai, Panjang sungai utama, dll. Unsur iklim yang sangat berpengaruh terhadap bentuk hidrograf satuan karakteristik dari hujan. Karakteristik hujan ini dapat berupa curah hujan total, intensitas hujan, lama waktu hujan, penyebaran hujan dan suhu (Asdak,2007).

Siklus hidrologi merupakan proses pengeluaran air dan perubahannya menjadi uap air yang mengembun kembali menjadi air yang berlangsung terus-menerus tiada henti-hentinya. Sebagai akibat terjadinya sinar matahari maka timbul panas. Dengan adanya panas ini maka air akan menguap menjadi uap air dari semua tanah, sungai, danau, telaga, waduk, laut, kolam, sawah dan lain-lain dan prosesnya disebut penguapan (evaporation).

Hidrologi secara gravitasi (alami) air mengalir dari daerah yang tinggi ke daerah yang rendah. Dari gunung-gunung, pegunungan ke lembah, lalu ke daerah yang lebih rendah sampai kedaeah pantai dan akhirnya akan bermuara ke laut. Aliran air ini disebut aliran permukan tanah karena bergerak diatas muka tanah. Aliran ini biasanya akan memasuki daerah tangkapan atau darah aliran menuju ke sistem jaringan sungai, sistem danau ataupun waduk. (Linsey,dkk,1982). 
Sebagian air hujan yang jatuh di permukaan bumi akan menjadi aliran permukaan (surface run off). Aliran permukaan sebagian akan meresap ke dalam tanah menjadi aliran bawah permukaan melalui proses infiltrasi (infiltration), dan perkolasi (percolation), selebihnya terkumpul didalam jaringan alur sungai (river flow). Apabila kondisi tanah memungkinkan, sebagian air infiltrasi akan mengalir kembali ke dalam sungai (river), atau genangan lainnya seperti waduk, danau sebagai interflow. Sebagian dari air dalam tanah dapat muncul lagi ke permukaan tanah sebagai air eksfiltrasi dan dapat berkumpul lagi dalam alur sungai atau langsung menuju ke laut. (Soewarno, 2000). Siklus hirologi dimulai dengan penguapan air dari laut. Uap yang dihasilkan dibawa oleh udara yang bergerak. Dalam kondisi yang memungkinkan, uap tersebut terkondensasi membentuk awan pada akhirnya dapat menghasilkan presipitasi. Presipitasi jatuh ke bumi menyebar dengan arah yang berbeda-beda dalam beberapa cara. Sebagian besar dari presipitasi tersebut sementara tertahan pada tanah di dekat tempat ia jatuh, dan akhirnya dikembalikan lagi ke atmosfer oleh penguapan (evaporasi) dan pemeluhan (transpirasi) oleh tanaman. Sebagian air mencari jalannya sendiri melalui permukaan dan bagian atas tanah menuju sungai, sementara lainnya menembus masuk lebih jauh ke dalam tanah menjadi bagian dari air tanah (groundwater). Di bawah pengaruh gaya gravitasi, baik aliran air permukaan (surface streamflow) maupun air dalam tanah bergerak ke tempat yang lebih rendah yang dapat mengalir ke laut. Namun, sejumlah besar air permukaan dan air tanah dikembalikan ke atmofer oleh penguapan dan pemeluhan (transpirasi) sebelum sampai ke laut. .

Sungai merupakan sumber air di darat yang paling dominan untuk memenuhi kebutuhan hidup manusia. Air yang jatuh ke permukaan tanah kemudian mengalir membentuk suatu alur dari hulu ke hilir, yang disebut sebagai daerah aliran sugai (DAS). Karakteristik DAS sangat mempengaruhi besar kecilnya aliran. Besar kecilnya aliran atau debit suatu DAS dapat dihitung dari data pencatatan curah hujan pada stasiun pengamatan curah hujan yang terdekat di kawasan tersebut. Variabel debit sungai dapat dipakai sebagai dasar kemungkinan debit masukan yang memadai bagi suatu kapasitas waduk tertentu. Daerah aliran sungai diartikan juga sebagai wilayah sungai yang dipisahkan dari wilayah lain oleh pemisah topografi yang berupa punggung bukit, tempat air hujan jatuh diwilayah tersebut, mengalir dan meresap menuju ke sungai dan mengalir ke laut. Garis batas daerah-daerah aliran yang berdampingan disebut batas daerah aliran sungai. Luas daerah aliran sungai dapat dihitung dengan menggunakan peta topografi (Suyono Sosrodarsono dalam Muhammad Fajar Angga Safrida, 2014).

Hujan merupakan salah satu penyebab alami banjir. Banjir terjadi akibat aliran langsung (direct runoff) yang terakumulasi dan tidak mampu ditampung oleh waduk ataupun saluran. Dalam memprediksi banjir, debit banjir rencana dapat diturunkan dari data curah hujan. Data curah hujan didapatkan dari stasiun hujan yang dipilih setelah dilakuka uji jaringan curah hujan, yang biasanya dilakukan dengan cara Kagan, yaitu dengan memilih stasiun yang terletak dititik segitiga sama sisi Kagan yang Panjang sisinya dihitung dari korelasi jarak antar stasiun DAS.

Cara mudah dalam pengambilan data hujan yang setiap hari turun dapat menggunakan Automatic Rainfall Recorder (ARR) yang dilengkapi dengan pencatat jumlah akumulasi hujan terhadap waktu dalam bentuk grafik. Ada tiga jenis alat penakar hujan otomatis yang biasa digunakan yaitu Weighing Bucket, Tipping Bucketand Fload. Sedangkan pengambilan data tinggi muka air biasanya menggunakan Automatic Water Level Recorder (AWLR) yaitu alat untuk mengukur tinggi muka air pada sungai, danau, ataupun aliran irigasi. AWLR merupakan alat pengganti sistem pengukuran tinggi air konvensional dimana perekaman data masih dilakukan secara manual sehingga sistem pengukuran dan penyimpanan data tidak tepat dan akurat. Alat ini banyak digunakan pada pengukuran parameter dalam kegiatan hidrologi pada daerah aliran sungai, pembuatan sumur patau, pertambangan dan lain-lain.

Dengan AWLR kita dapat melakukan berbagai aplikasi dibidang hidrologi seperti dapat mengetahui suatu kondisi suatu DAS serta dapat berfungsi juga sebagai sistem peringatan dini 
terhadap banjir pada suatu DAS. Data dari stasiun hujan terpilih selanjutnya diuji untuk mengetahui kepanggahan data yang tercatat. Hal ini diperlukan untuk mengantisipasi adanya data yang tidak valid akibat pencatatan maupun hal lainnya. Stasiun hujan dengan data yang dianggap panggah dapat digunakan datanya untuk perhitungan hidrologi. Dalam perencanaan, data hujan dari stasiun hujan ditransformasi menjadi hujan wilayah. Hujan wilayah diperlukan untuk menentukan besarnya debit yang dihasilkan akibat hujan yang jatuh pada luasan tertentu berdasarkan stasiun hujan yang dianggap mewakili luasan tersebut.

Perhitungan debit pada tahap selanjutnya data hujan harian dicari pola gihan jam-jamya Pola agihan hujan menggambarkan intensitas hujan yang turun tiap jam dalam bentuk hidrograf. Dari hidrograf dapat diketahui waktu puncak terjadinya hujan yang digunakan sebagai dasar intensitas hujan rencana.Sebelum diturunkan menjadi debit, perlu dilakukan pengurangan hujan rencana akibat adanya proses infiltrasi. Hujan yang telah dikurangi infiltrasi disebut sebagai hujan sisa (excess rainfall) yang kemudian mengalir di permukaan tanah dipengaruhi oleh kondisi permukaan tanah dan penutup lahan, jenis tanah dan moisture content (Chow, dkk 1988). Aliran di permukaan tanah akan terakumulasi di saluran dan berubah menjadi aliran yang dinamakan aliran di alur sungai (channel flow).

Hujan wilayah adalah rata-rata curah hujan diseluruh daerah pengamatan, bukan curah hujan dari 1 titik pengamatan. Satu titik pengukuran curah hujan tidak dapat mewakili volume curah hujan yang jatuh pada suatu tempat. Cara perhitungan curah hujan wilayah dari pengamatan hujan dibeberapa titik dibagi menjadi tiga metode yaitu metode rerata aritmatik, metode Poligon Thiessen dan metode Isohiet (Bambang Triatmodjo, 2008)

Periode ulang adalah waktu hipotetik dimana hujan dengan suatu besaran tertentu $\left(\mathrm{x}_{\mathrm{T}}\right)$ akan disamai atau dilampaui dalam jangka waktu misalnya 2, 5, 10, 25, 50, 100, 200, dan 1000 tahun sekali (Bambang Triatmodjo, 2010). Perhitungan hujan periode ulang dimaksudkan untuk menghitung hujan rencana. Hujan rencana akan digunakan sebagai data masukan untuk perhitungan hidrograf. Perhitungan periode ulang didasarkan pada analisis distribusi frekuensi.

Analisis distribusi frekuensi ini didasarkan pada sifat statistic data kejadian yang telah lalu untuk memperoleh probabilitas besaran hujan di masa yang akan datang dengan anggapan bahwa sifat statistik kejadian hujan masa lalu. Ada beberapa bentuk fungsi distribusi yang sering digunakan dalam analisis frekuensi untuk hidrologi seperti Distribusi Normal, Log Normal, Gumbel, dan Log Pearson Type III. Istilah hydrograph (hidrograf) digunakan untuk menyebut suatu grafik (kurva) yang menggambarkan fluktuasi naik dan turunnya aliran air pada lokasi tertentu di sungai sebagai fungsi waktu. SCS (1989) mendefinisikan hidrograf sebagai berikut: " A hydrograph is a graph showing stage, discharge, velocity, or orther properties of water flow with respect to time". Hidrograf adalah suatu grafik yang menunjukkan hubungan antara tinggi muka air (stage) atau tma, debit (discharge, flow, streamflow), kecepatan (velocity) atau karakteristik aliran air terhadap waktu. Debit menyatakan volume air per satuan waktu tertentu.

Metode hidrograf satuan banyak digunakan untuk memperkirakan banjir rancangan. Metode ini relatif sederhana, mudah perapannya, tidak memerlukan data yang kompleks dan memberikan hasil rancangan yang cukup teliti. Data yang diperlukan untuk menurunkan hidrograf satuan terukur di DAS yang ditinjau adalah data hujan otomatis dan pencatatan debit di titik control.

\section{Metode Penelitian}

\subsection{Lokasi Penelitian}

Pada penelitian ini lokasi penelitian dilakukan pada DAS Kayan Kabupaten Bulungan. Dapat dilihat pada gambar di bawah ini. 


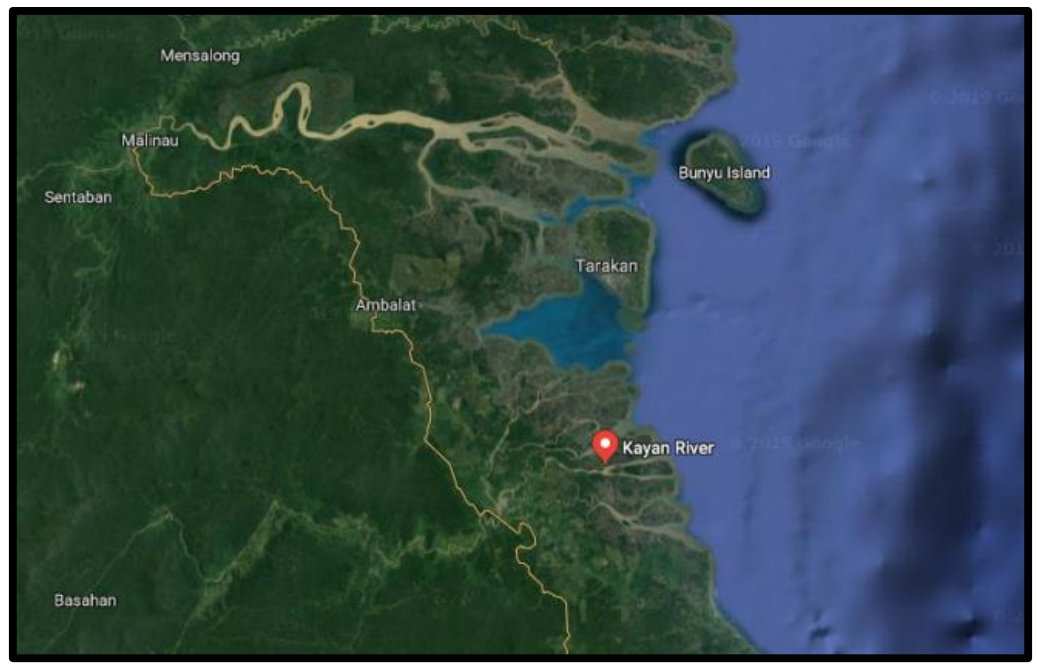

Gambar 1 Lokasi Penelitian

\subsection{Data Penelitian}

Pada Penelitian ini dibagi menjadi tiga bagian besar yakni pengumpulan data, Analisa data (perhitungan data), dan kesimpulan hasil analisis. Data yang diperlukan dalam penyelesaian penelitian ini berupa data sekunder yang diperoleh dari BMKG Tanjung Selor dan DPUTR Provinsi Kalimantan Utara. Data-data tersebut diantaranya :

1. Data curah hujan DAS Kayan dengan periode waktu dari tahun 2007 sampai tahun 2016.

2. Data deskripsi DAS Kayan, dan data-data penunjang lainnya

\subsection{Pengolahan data}

Perhitungan pertama akan mencari curah hujan harian maksimum dengan menggunakan metode rerata aritmatik aljabar, lalu menghitung analisis frekuensi curah hujan, kemudian analisis curah hujan rencana dengan menggunakan metode distribusi Log Pearson III, selanjutnya menghitung uji kecocokan Smirnov-Kolmogorov dan mencari distribusi curah hujan jam-jaman dengan metode Mononobe, setelah itu baru bisa mencari bentuk serta debit puncak dengan metode HSS Snyder dan HSS Nakayasu.

\section{Hasil dan Pembahasan}

Berdasarkan data studi Dinas Pekerjaan Umum Provinsi Kaltara Sungai kayan adalah sungai terbesar di Kalimantan Utara, dengan Panjang sungai utama mencapai $576 \mathrm{~km}$ dan luas Daerah Aliran Sungai (DAS) adalah $33.005 \mathrm{~km}^{2}$. Sungai Kayan letaknya diapit oleh 2 wilayah sungai Berau-Kelai dan wilayah Sungai Mahakam. Wilayah administrasi yang terkait dalam wilayah Sungai Kayan terletak sebagian besar pada wilayah administrasi Kabupaten Malinau, Kabupaten Bulungan dan sebagian kecil masuk pada wilayah Kabupaten Berau dan Kabupaten Kutai Kertanegara. Keempat wilayah kabupaten tersebut secara astronomi terletak pada posisi $114^{0} 12^{\prime}-$ $118^{0} 2^{\prime}$ Bujur Timur dan $3^{0} 54^{\prime}-1^{0} 6^{\prime}$ Lintang Utara.

\subsection{Kondisi Fisik DAS Kayan}

\subsubsection{Geologi}

Keadaan geologi di wilayah pekerjaan dalam Wilayah Sungai Kayan didominasi oleh batuan sedimen liat berlempung, disamping itu juga terdapat kandungan batuan endapan tersier dan batuan 
endapan kwarter. Formasi batuan endapan utama terdiri dari batuan pasir kwarsa dan batuan liat. Dari struktur geologi, di daerah Wilayah Sungai Kayan banyak dijumpai patahan dan lipatan yang terdapat di daerah pantai.

\subsubsection{Geomorfologi}

Sebagian besar wilayah hulu, tengah dan hilir Sungai Kayan yang wilayah mencakup Kabupaten Malinau dan Kabupaten Bulungan didominasi oleh sebaran jenis batuan komposisi lithologi batuan beku / malihan yang bersifat kedap terhadap resapan air.

\subsubsection{Hidroklimatologi}

Berdasarkan pengamatan di Stasiun Iklim Tanjung Selor, memberikan data suhu udara rata - rata bulanan diwilayah hilir sebagai berikut, untuk suhu minimum berkisar $22,50-22,80^{\circ} \mathrm{C}$ dan untuk suhu maksimum berkisar $34,50-34,90^{\circ} \mathrm{C}$, serta tinggi curah hujan rata - rata bulanan mencapai nilai antara 210 - 265 mm. (sumber data: Kabupaten Bulungan Dalam Angka 2008).

\subsubsection{Hidrogeologi}

Sebagian besar wilayah Sungai Kayan tertutup jenis batuan beku/malihan yang bersifat tidak dapat menyimpan air, sehingga terkondisi dapat menyimpan air tergantung lapisan humus yang terbentuk oleh hutan tutupan lahan. Keadaan kondisi daerah tersebut diatas menjadi sangat rawan terhadap perubahan daerah menjadi daerah lahan lolos air bila hutan tutupan lahan rusak, gundul dan atau terbakar.

\subsection{Analisis Hidrologi}

\subsubsection{Curah hujan harian maksimum}

Data curah hujan yang digunakan tercatat mulai tahun 2007 sampai 2016. Dari curah hujan harian maksimum dilakukan perhitungan untuk mengetahui rata-rata curah hujan harian maksimum setiap tahunnya pada DAS Kayan. Metode yang digunakan adalah metode rata-rata aljabar dikarenakan jumlah stasiun hujan yang sedikit. Berdasarkan data perhitungan curah hujan harian maksimum tahunan terendah terjadi pada tahun 2012 dengan curah hujan sebesar $82.6 \mathrm{~mm}$ dan curah hujan tahunan tertinggi terjadi pada tahun 2017 dengan curah hujan sebesar $155.7 \mathrm{~mm}$.

Tabel 1. Urutan data curah hujan maksimum tahunan

\begin{tabular}{ccc}
\hline No. & Tahun & Hujan Maksimum \\
\hline 1 & 2008 & 86.1 \\
2 & 2009 & 153.0 \\
3 & 2010 & 89.6 \\
4 & 2011 & 125.5 \\
5 & 2012 & 82.6 \\
6 & 2013 & 113.1 \\
7 & 2014 & 102.4 \\
8 & 2015 & 125.3 \\
9 & 2016 & 124.0 \\
10 & 2017 & 155.7 \\
\hline
\end{tabular}




\subsubsection{Analisis frekuensi curah hujan}

Analisis frekuensi ini didasarkan pada sifat statistik data kejadian yang telah lalu untuk memperoleh probabilitas besaran hujan di masa yang akan datang. Dengan anggapan bahwa sifat statistik kejadian hujan yang akan datang masih sama dengan sifat statistik kejadian masa lalu.

Tabel 2. Analisis frekuensi curah hujan

\begin{tabular}{cccccc}
\hline Data & $\begin{array}{c}\text { Curah hujan } \\
(\mathbf{X i})\end{array}$ & $(\mathbf{X i - X r})$ & $(\mathbf{X i - X r ) 2}$ & $(\mathbf{X i - X r ) 3}$ & $(\mathbf{X i - X r ) 4}$ \\
\hline 1 & 82.6 & -33.13 & 1097.5969 & -36363.3853 & 1204718.955 \\
2 & 86.1 & -29.63 & 877.9369 & -26013.27035 & 770773.2004 \\
3 & 89.6 & -26.13 & 682.7769 & -17840.9604 & 466184.2952 \\
4 & 102.4 & -13.33 & 177.6889 & -2368.593037 & 31573.34518 \\
5 & 113.1 & -2.63 & 6.9169 & -18.191447 & 47.84350561 \\
6 & 124.0 & 8.3 & 68.3929 & 565.61 & 4677.59 \\
7 & 125.3 & 9.57 & 91.5849 & 876.467493 & 8387.79 \\
8 & 125.5 & 9.77 & 95.4529 & 932.574833 & 9111.256118 \\
9 & 153.0 & 37.3 & 1389.0529 & 51770.00 & 1929467.96 \\
10 & 155.7 & 39.97 & 1597.6009 & 63856.10797 & 2552328.636 \\
\hline Jumlah & 1157.3 & & 6085.001 & 35396.36064 & 6977270.873 \\
Rata- & & & & & \\
Rata (Xr) & & & & & \\
\hline
\end{tabular}

\subsubsection{Analisis jenis distribusi}

Untuk menentukan jenis sebaran yang akan digunakan dalam menetapkan periode ulang/ returny (analisis frekuensi) maka dicari parameter statistic dari data curah hujan wilayah baik secara normal maupun secara logaritmik. Langkah yang ditempuh adalah dengan menggunakan data yang terkecil sampai data yang terbesar. Dari hasil analisis diperoleh nilai untuk masing-masing parameter statistik. Dari data analisis frekuensi curah hujan yang telah dihitung metode perhitungan curah hujan rencana jenis distribusi yang digunakan yaitu distribusi Log Pearson III.

\subsubsection{Analisis curah hujan rancangan dengan metode distribusi Log Pearson III}

Adapun faktor-faktor yang diperoleh untuk perhitungan log pearson III adalah sebagai berikut :

- $\quad$ Rata-rata curah hujan $(\mathrm{Xr})$ dengan nilai 115.73

- $\quad$ Standar deviasi dengan nilai 26.002

- Variabel reduksi berdasarkan koefisien kemencengan (K)

Selanjutnya dari ketiga faktor tersebut dapat dilakukan perhitungan analisis curah hujan rencana dengan metode Log Pearson III.

Tabel 3. Analisis curah hujan rencana dengan distribusi Log Pearson III

\begin{tabular}{ccccc}
\hline Periode Ulang & $\mathbf{X r}$ & $\mathbf{K}$ & $\mathbf{S}$ & Curah hujan (mm) \\
\hline 2 & 115.73 & -0.058 & 26.002 & 114.22188 \\
5 & 115.73 & 0.824 & 26.002 & 137.15576 \\
10 & 115.73 & 1.309 & 26.002 & 149.76680 \\
25 & 115.73 & 1.849 & 26.002 & 163.80795 \\
50 & 115.73 & 2.211 & 26.002 & 173.22073 \\
100 & 115.73 & 2.544 & 26.002 & 181.87944 \\
\hline
\end{tabular}




\subsubsection{Uji Kesesuian Distribusi Smirnov-Kolmogorov}

Uji kecocokan Smirnov-Kolmogorov sering juga disebut uji kecocokan non parametic (non parametic test), karena pengujiannya tidak menggunakan fungsi distribusi tertentu. Dari hasil perhitungan diperoleh nilai Dmax $=0,202$. Sedangkan nii D Kritis Smirnov-Kolmogorov didapatkan $\operatorname{Dcr}(0,05)=0,41$.

\subsubsection{Distribusi hujan jam-jaman}

Perhitungan distribusi hujan jam-jaman menggunakan metode Mononobe . Dari hasil perhitungan, akan diperoleh curah hujan rencana dengan periode ulang tertentu dimana pendistribusian hujan jam-jaman ini akan dimasukkan ke dalam perhitungan Hidrograf Satuan Sintetis sehingga dapat diketahui besarnya debit banjir akibat hujan.

Tabel 4. Perhitungan distribusi hujan jam-jaman

\begin{tabular}{|c|c|c|c|c|c|c|c|c|c|c|}
\hline \multirow{3}{*}{$\begin{array}{c}\begin{array}{c}\text { Waktu } \\
\text { (Jam) }\end{array} \\
1\end{array}$} & \multicolumn{4}{|c|}{ Pola Hujan Jam-Jaman } & \multicolumn{6}{|c|}{ Curah Hujan Rencana (mm) } \\
\hline & \multicolumn{2}{|c|}{$\mathbf{R t}$} & \multicolumn{2}{|c|}{ Rt } & \multirow{2}{*}{$\begin{array}{c}\begin{array}{c}\mathbf{2} \\
\text { tahun }\end{array} \\
28.29\end{array}$} & \multirow{2}{*}{$\begin{array}{c}\begin{array}{c}5 \\
\text { tahun }\end{array} \\
33.97\end{array}$} & \multirow{2}{*}{$\begin{array}{c}\begin{array}{c}\mathbf{1 0} \\
\text { tahun }\end{array} \\
37.09\end{array}$} & \multirow{2}{*}{$\begin{array}{c}\begin{array}{c}25 \\
\text { tahun }\end{array} \\
40.57\end{array}$} & \multirow{2}{*}{$\begin{array}{c}\begin{array}{c}50 \\
\text { tahun }\end{array} \\
42.90\end{array}$} & \multirow{2}{*}{$\begin{array}{c}\begin{array}{c}100 \\
\text { tahun }\end{array} \\
45.04\end{array}$} \\
\hline & 0.5503 & $\mathrm{R}_{24}$ & 0.5503 & $\mathrm{R}_{24}$ & & & & & & \\
\hline 2 & 0.3467 & $\mathrm{R}_{24}$ & 0.1430 & $\mathrm{R}_{24}$ & 7.35 & 8.83 & 9.64 & 10.54 & 11.15 & 11.71 \\
\hline 3 & 0.2646 & $\mathrm{R}_{24}$ & 0.1003 & $\mathrm{R}_{24}$ & 5.16 & 6.19 & 6.76 & 7.39 & 7.82 & 8.21 \\
\hline 4 & 0.2184 & $\mathrm{R}_{24}$ & 0.0798 & $\mathrm{R}_{24}$ & 4.10 & 4.92 & 5.38 & 5.88 & 6.22 & 6.53 \\
\hline 5 & 0.1882 & $\mathrm{R}_{24}$ & 0.0674 & $\mathrm{R}_{24}$ & 3.47 & 4.16 & 4.54 & 4.97 & 5.26 & 5.52 \\
\hline 6 & 0.1667 & $\mathrm{R}_{24}$ & 0.0590 & $\mathrm{R}_{24}$ & 3.03 & 3.64 & 3.98 & 4.35 & 4.60 & 4.83 \\
\hline \multicolumn{5}{|c|}{ Hujan Rancangan } & 114.22 & 137.16 & 149.77 & 163.81 & 173.22 & 181.88 \\
\hline \multicolumn{5}{|c|}{ Koefisien pengaliran } & 0.45 & 0.45 & 0.45 & 0.45 & 0.45 & 0.45 \\
\hline \multicolumn{5}{|c|}{ Hujan Efektif } & 51.39 & 61.71 & 67.39 & 73.70 & 77.94 & 81.84 \\
\hline
\end{tabular}

\subsection{Hidrograf Satuan Sintetis}

Teori klasik hidrograf satuan berasal dari hubungan antara hujan efektif dengan limpasan langsung. Hubungan tersebut merupakan salah satu komponen model watershed yang umum. Teori hidrograf satuan merupakan penerapan pertama teori system linier dalam hidrologi (Soemarto,1987). Didaerah dimana data hidrologi tidak tersedia untuk menurunkan hidrograf satuan, maka dibuat hidrograf satuan sintetis (HSS) yang didasarkan pada karakteristik fisik dari DAS. HSS Snyder dan HSS Nakayasu adalah dua metode yang biasa digunakan.

\subsubsection{Hidrograf Satuan Sintetis Snyder (HSS)}

Dalam permulaan tahun 1938, F.F. Snyder dari Amerika Serikat, telah mengembangkan rumus dengan koefisien-koefisien empiris yang menghubungkan unsur-unsur hidrograf satuan dengan karakteristik daerah pengaliran (C.D. Soemarto, 1999) Hidrograf satuan tersebut ditentukan dengam cukup baik pada tinggi $\mathrm{d}=1 \mathrm{~mm}$, dan dengan ketiga unsur yang lain, yaitu $\mathrm{Q}$ (m3/detik), $\mathrm{Tb}$ serta $\operatorname{tr}(\mathrm{jam})$. Unsur-unsur hidrograf tersebut dihubungkan dengan luas daerah pengaliran $(\mathrm{km} 2)$, Panjang aliran utama $(\mathrm{km})$ dan jarak antara titik berat daerah pengaliran dengan pelepasan (outlet) yang diukur sepanjang aliran utama (C.D. Soemarto, 1999). Berikut hasil perhitungan dengan 
menggunakan parameter-parameter tertentu didapatkan nilai debit puncak terlampir pada tabel dibawah.

Tabel 5. Parameter hidrograf satuan sintetis Snyder

\begin{tabular}{|c|c|c|c|c|}
\hline Variabel/parameter & Notasi & Asal/Rumus & Nilai & Satuan \\
\hline Luas DAS & A & Data & 33005 & $\mathrm{~km}^{2}$ \\
\hline Panjang Sungai Utama & $\mathrm{L}$ & Data & 576,00 & $\mathrm{~km}$ \\
\hline Jarak titik berat DAS-outlet & Lc & Data & 270,00 & $\mathrm{~km}$ \\
\hline Durasi hujan satuan & $\operatorname{Tr}$ & Teori & 1 & Jam \\
\hline Tinggi hujan satuan & $\mathrm{H}$ & Teori & 1 & Jam \\
\hline Waktu dari titik berat hujan ke puncak & $t_{p}$ & $C_{t} .\left(L . L_{c}\right)^{0.3}$ & 70,40 & Jam \\
\hline Durasi curah hujan efektif & $\mathrm{Te}$ & $\mathrm{tp} / 5,5$ & 12,80 & Jam \\
\hline Waktu dari mulai hujan ke puncak & $\mathrm{Tp}$ & $t p+(t r / 2)$ & 73,85 & Jam \\
\hline Debit puncak & Qp & qp.A & 118,0 & $\mathrm{~m}^{3} / \mathrm{det}$ \\
\hline Parameter rumus a & $\lambda$ & $\left(Q_{p} x T_{p}\right)$ & 0,95 & Metrik \\
\hline Parameter Rumus Y & $\mathrm{a}$ & $\begin{array}{l}\quad(h \times A) \\
1,32 \lambda^{2}+0,15 \lambda \\
+0,045\end{array}$ & 1,38 & Metrik \\
\hline Rumus X & $\mathrm{X}$ & $\mathrm{t} / \mathrm{TP}$ & 1,000 & Metrik \\
\hline Rumus Y & Y & $10^{-a(1-x)^{2} / x}$ & 1,000 & Metrik \\
\hline Q & Q & Y.Qp & 118,0 & $\mathrm{~m}^{3} / \mathrm{det}$ \\
\hline
\end{tabular}

Tabel 6. Debit banjir rancangan berbagai periode ulang

\begin{tabular}{ccc}
\hline No & Periode Ulang & Debit Banjir $\left(\mathbf{m}^{\mathbf{3}} / \mathbf{d e t}\right)$ \\
\hline 1. & 2 tahun & 6057,04 \\
2. & 5 tahun & 7273,19 \\
3. & 10 tahun & 7941,94 \\
4. & 25 tahun & 8686,52 \\
5. & 50 tahun & 9185,67 \\
6. & 100 tahun & 9644,83 \\
\hline
\end{tabular}

Adapun grafik perbandingan debit hidrograf satuan sintetis Snyder berdasarkan hujan rencana dari periode ulang 2 tahun - 100 tahun dapat dilihat pada gambar berikut.

\subsubsection{Hidrograf satuan sintetis Nakayasu}

Hidrograf Satuan Sintetis (HSS) Nakayasu dikembangkan berdasarkan beberapa sungai di Jepang (Soemarto, 1987). Penggunaan metode ini memerlukan beberapa karakteristik parameter daerah alirannya, seperti :

a. Tenggang waktu dari permukaan hujan sampai puncak hidrograf (time of peak)

b. Tenggang waktu dari titik berat hujan sampai titik berat hidrograf (time lag)

c. Tenggang waktu hidrograf (time base of hydrograph) 
d. Luas daerah aliran sungai

e. Panjang alur sungai utama terpanjang (length of the longest channel).

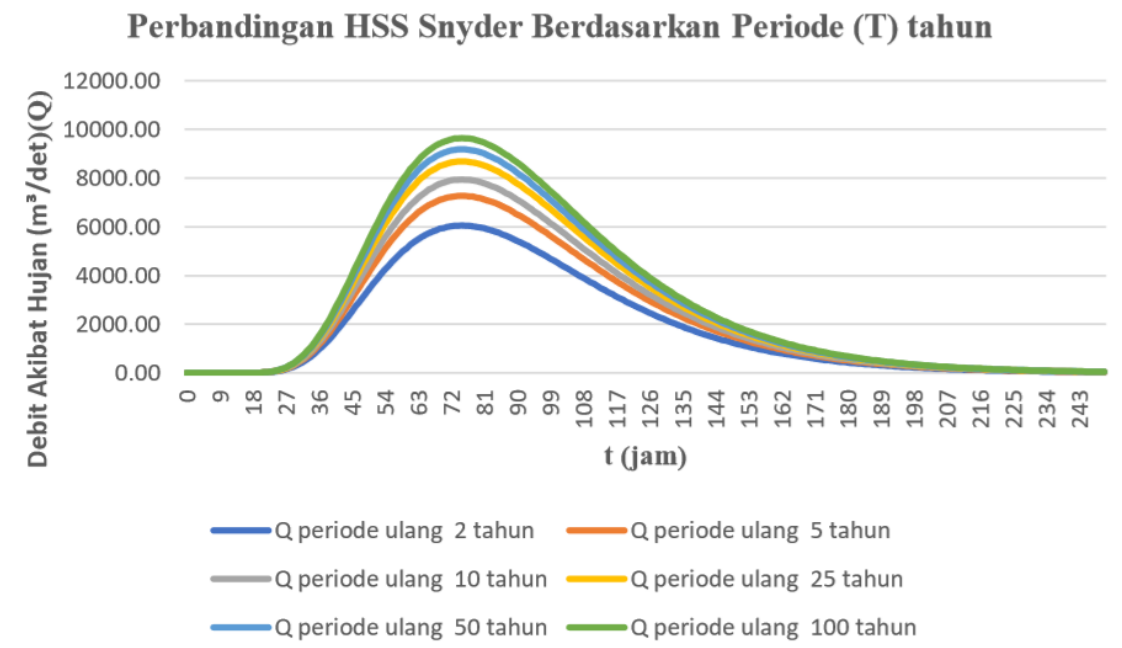

Gambar 2. Grafik hidrograf satuan sintetis (HSS) Snyder berdasarkan hujan rencana periode ulang 2 tahun - 100 tahun

Agar perhitungan parameter hidrograf diatas mudah dipahami, berikut rekapitulasi perhitungan hidrograf satuan sintetis Nakayasu.

Tabel 7.parameter hidrograf satuan sintetis Nakayasu

\begin{tabular}{|c|c|c|c|c|}
\hline Variabel/parameter & Notasi & Asal/Rumus & Nilai & Satuan \\
\hline Luas DAS & $\mathrm{CA}$ & Data & 33005 & $\mathrm{~km}^{2}$ \\
\hline Panjang Sungai Utama & $\mathrm{L}$ & Data & 576,00 & $\mathrm{~km}$ \\
\hline Harga satuan & Ro & Teori & 1,00 & $\mathrm{~mm}$ \\
\hline Waktu konsentrasi hujan & $\mathrm{t}_{\mathrm{r}}$ & $0,5 \times \mathrm{t}_{\mathrm{g}}$ & 25,36 & jam \\
\hline $\begin{array}{l}\text { Waktu permulaan hujan sampai } \\
\text { puncak banjir }\end{array}$ & $\mathrm{T}_{\mathrm{p}}$ & $t_{g}+0,8 t_{r}$ & 54,09 & jam \\
\hline Waktu penurunan debit & T0,3 & $\alpha \times \mathrm{t}_{\mathrm{g}}$ & 67,62 & jam \\
\hline Debit maksimum & $\mathrm{Q}_{\mathrm{p}}$ & CA. $R_{0}$ & 109,35 & $\mathrm{~m}^{3} /$ det \\
\hline Kurva naik $(\mathrm{t}=30$ jam $)$ & Qt & $\begin{array}{r}3,6\left(0,3 \mathrm{~T}_{\mathrm{p}}+\mathrm{T}_{0,3}\right) \\
Q p(t / T p)^{2,4}\end{array}$ & 26,57 & $\mathrm{~m}^{3} / \mathrm{det}$ \\
\hline Kurva turun pertama $(\mathrm{t}=90 \mathrm{jam})$ & Qt1 & $\mathrm{Qp}_{\mathrm{p} .0,3} \frac{\mathrm{t}-\mathrm{T} \mathrm{p}}{\mathrm{T} 0.3}$ & 57,69 & $\mathrm{~m}^{3 / \mathrm{det}}$ \\
\hline Kurva turun kedua $(\mathrm{t}=180 \mathrm{jam})$ & Qt2 & $\left.\mathrm{Q}_{\mathrm{p} \cdot 0,3} \frac{\mathrm{t}-\mathrm{T}}{1,5 \mathrm{p}+(0,5 \cdot \mathrm{T} 0,3} \underline{0,3}\right)$ & 16,42 & $\mathrm{~m}^{3} / \mathrm{det}$ \\
\hline Kurva turun ketiga $(\mathrm{t}=240$ jam $)$ & Qt3 & $\mathrm{Q}_{\mathrm{p}} .0,3 \quad \frac{\mathrm{t}-\mathrm{T}}{2} \underline{\mathrm{p}}+\frac{(1,5 \mathrm{~T}}{2 . \mathrm{T}_{0,3}} \underline{0,3)}$ & 8,47 & $\mathrm{~m}^{3} / \mathrm{det}$ \\
\hline
\end{tabular}


Tabel 8. Debit banjir rancangan berbagai periode ulang

\begin{tabular}{ccc}
\hline No & Periode Ulang & Debit Banjir $\left(\mathbf{m}^{\mathbf{3} / \mathbf{d e t})}\right.$ \\
\hline 1. & 2 tahun & 5401,87 \\
2. & 5 tahun & 6486,48 \\
3. & 10 tahun & 7082,89 \\
4. & 25 tahun & 7746,94 \\
5. & 50 tahun & 8192,10 \\
6. & 100 tahun & 8601,59 \\
\hline
\end{tabular}

Dibawah ini grafik perbandingan debit hidrograf satuan sintetis Nakayasu berdasarkan hujan rencana dari periode ulang 2 tahun - 100 tahun dapat dilihat pada gambar berikut.

\section{Perbandingan HSS Nakayasu Berdasarkan Periode Ulang}

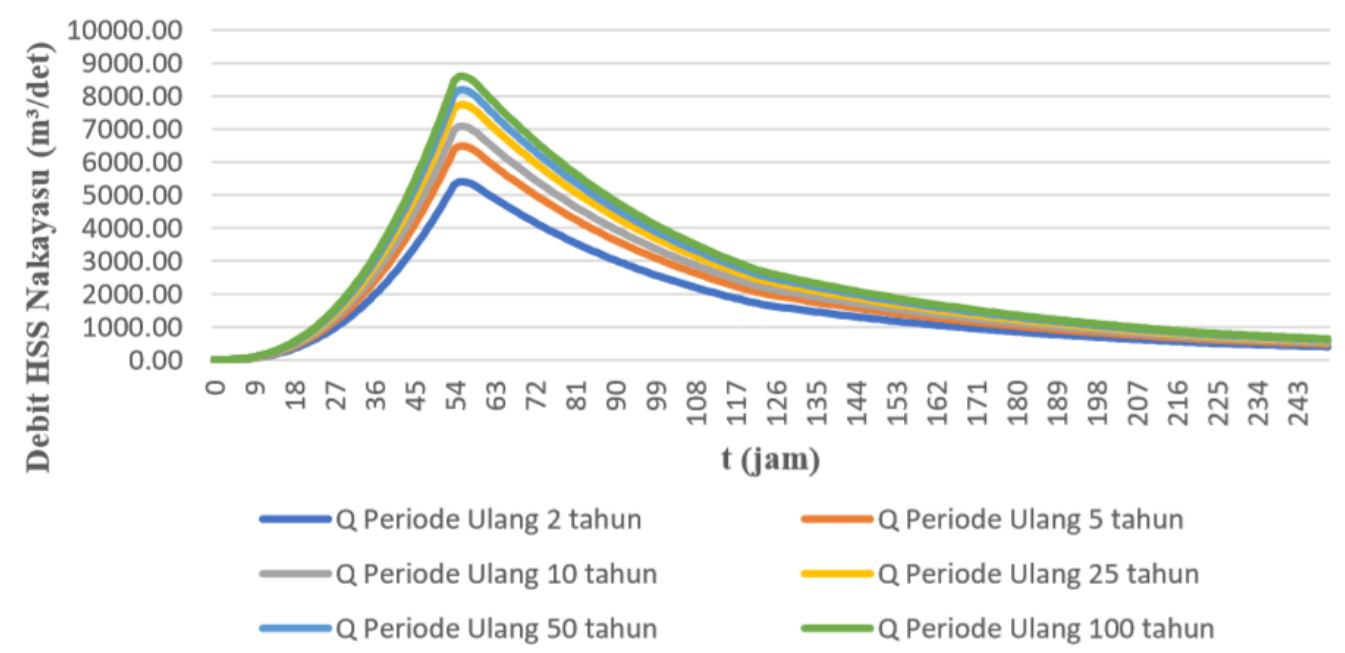

Gambar 3. Grafik hidrograf satuan sintetis (HSS) Nakayasu berdasarkan hujan rencana periode ulang 2 tahun -100 tahun.

Berikut rekapitulasi perhitungan menggunakan HSS Snyder dan HSS Nakayasu dan juga perbandingan antara parameter HSS Snyder dan Parameter HSS Nakayasu.

Tabel 9. Rekapitulasi Debit Puncak HSS Snyder dan HSS Nakayasu

\begin{tabular}{cccc}
\hline No & $\begin{array}{c}\text { Kala Ulang } \\
\text { (tahun) }\end{array}$ & $\begin{array}{c}\text { Metode Snyder } \\
\mathbf{m}^{\mathbf{3}} / \mathbf{d e t}\end{array}$ & $\begin{array}{c}\text { Metode Nakayasu } \\
\mathbf{m}^{\mathbf{3} / \mathbf{d e t}}\end{array}$ \\
\hline 1 & 2 & 6057,04 & 5401,87 \\
2 & 5 & 7273,19 & 6486,48 \\
3 & 10 & 7941,94 & 7082,89 \\
4 & 25 & 8686,52 & 7746,94 \\
5 & 50 & 9185,67 & 8192,10 \\
6 & 100 & 9644,83 & 8601,59 \\
\hline
\end{tabular}


Tabel 10. Perbandingan parameter HSS Snyder dan HSS Nakayasu

\begin{tabular}{ccc}
\hline No & HSS Snyder & HSS Nakayasu \\
\hline 1. & Luas DAS & Luas DAS \\
2. & Panjang Sungai Utama & Panjang Sungai Utama \\
3. & Jarak titik berat DAS-outlet & Harga satuan \\
4. & Durasi hujan satuan & Waktu konsentrasi hujan \\
5. & Tinggi hujan satuan & Waktu permulaan hujan sampai puncak banjir \\
6. & Waktu dari titik berat hujan ke puncak & Waktu penurunan debit \\
7. & Durasi curah hujan efektif & Debit maksimum \\
8. & Waktu dari mulai hujan ke puncak & Kurva naik (t=30 jam) \\
9. & Debit puncak & Kurva turun pertama (t=90 jam) \\
10. & Parameter rumus a & Kurva turun kedua (t=180 jam) \\
11. & Parameter Rumus Y & Kurva turun ketiga (t=240 jam) \\
12. & Rumus X & - \\
13. & Rumus Y & - \\
14. & Q & - \\
\hline
\end{tabular}

Hasil yang didapat dari perbandingan 2 metode diatas yaitu, perhitungan debit banjir menggunakan metode HSS Snyder dan HSS Nakayasu memiliki nilai yang tidak sama. Ini dapat terjadi karena setiap metode memiliki parameter yang berbeda-beda pula. Dalam perhitungan diatas didapatkan nilai Tp dan Qp terbesar pada metode HSS Snyder sedangkan Tp dan Qp terkecil pada metode HSS Nakayasu. Penulis tidak dapat menyimpulkan bahwa hasil perhitungan Tp dan Qp terkecil adalah metode perhitungan Hidrograf Satuan Sintetis (HSS) yang terbaik. Setiap Daerah Aliran Sungai (DAS) memiliki karakteristiknya masing-masing. Oleh karena itu tiap metode tidak dapat digunakan untuk menghitung semua Daerah Aliran Sungai (DAS) yang ada, sehingga semua metode Hidrograf Satuan Sintetis (HSS) dianggap baik.

\section{Kesimpulan}

Berdasarkan perhitungan debit banjir menggunakan metode HSS Snyder pada Sungai Kayan mencapai debit puncak pada 73,85 jam dengan $\mathrm{Q}=118,0 \mathrm{~m}^{3} /$ det.Sedangkan debit banjir menggunakan metode HSS Nakayasu pada Sungai Kayan mencapai debit puncak pada 54,09 jam dengan $\mathrm{Q}=109,35 \mathrm{~m}^{3} / \mathrm{det}$.

\section{Ucapan terima kasih}

Penulis mengucapkan terima kasih kepada Dinas Pekerjaan Umum dan Tata Ruang (DPUTR) Provinsi Kalimantan Utara dan Badan Meteorologi Klimatologi dan Geofisika (BMKG) Tanjung Selor yang telah bersedia memberikan data hidrologi dan data lainnya sehingga dapat dimanfaatkan untuk penelitian ini. Terakhir penulis ingin mengucapkan terima kasih kepada semua pihak yang telah membantu selesainya karya ilmiah ini

\section{DAFTAR PUSTAKA}

Asdak C, 1995, Hidrologi dan Pengelolaan Daerah Aliran Sungai, Gadjah Mada University Press, Yogyakarta.

B.R. Sri Harto, 1993, Analisis Hidrologi, Gramedia Pustaka Utama, Jakarta.

C.D. Soemarto, 1999, Hidrologi Teknik, Erlangga, Jakarta.

Chow,Van Te, 1992, Hidrolika Saluran Terbuka, Erlangga, Jakarta. 
Linsley,R.K,dkk, 1982, Hidrologi Untuk Insinyur Edisi Ketiga, Erlangga, Jakarta.

Safrida,M.F.A, 2014, Analisis Hidrograf Aliran Daerah Aliran Sungai Tirtomulyo

Dengan Beberapa Metode Hidrograf Satuan Sintetik, Skripsi, Universitas sebelas maret, Surakarta.

Soemarto, 1987, Hidrologi Teknik, Erlangga, Jakarta.

Soewarno, 2000, Hidrologi Operasional Jilid Kesatu, PT.Aditya Bakti, Bandung.

Triatmodjo, B, 2008, Hidrologi Terapan, Beta Offset, Yogyakarta. 
